\title{
Investigating a Prototype Heat Exchanger for Steam Storage
}

\author{
Kawira M. K* Kinyua $\mathrm{R}^{2}$ and Kamau J. N ${ }^{3}$ \\ ${ }^{1}$ Institute of Energy and Envronmental Studies, Jomo Kenyatta University of Agriculture and Technology, P. O. \\ Box 62000, Nairobi. \\ ${ }^{2}$ Institute of Energy and Envronmental Studies, Jomo Kenyatta University of Agriculture and Technology, P. O. \\ Box 62000, Nairobi. \\ ${ }^{3}$ Department of Physics, Jomo Kenyatta University of Agriculture and Technology, P. O. Box 62000, Nairobi. \\ ${ }^{*}$ Millien Kawira
}

\begin{abstract}
A coiled tube single pass counter flow heat exchanger was designed and fabricated using locally available materials and its capacity to transmit heat to water to make steam was tested. The heat exchanger was part of components used in solar thermal power production using a parabolic trough solar concentrator. The design of the heat exchanger storage system was done using Auto CAD 2010 software. Higher temperatures of steam were realized when the heat exchanger was used as a steam storage system. The heat transfer fluids used were locally available and they were water, sunflower oil, Rina oil, used engine oil, unused engine oil, $2 \mathrm{M}$ sodium chloride salt solution, $4 \mathrm{M}$ sodium chloride salt solution and $6 \mathrm{M}$ sodium chloride solution. For each of the heat transfer fluids, heat exchanger operating points were obtained and it was operated between $1.0 \times 10^{5}$ $\mathrm{Nm}^{-2}$ to $1.0 \times 10^{6} \mathrm{Nm}^{-2}$ of pressure. In the study the number of heat transfer units of the heat exchanger obtained was 0.61 and the thermal efficiency was found as 0.91. The average rates of heat transfer were 68.4 $\mathrm{J} \mathrm{s}^{-1} \mathrm{~kg}^{-1}$ for $6 \mathrm{M}$ sodium chloride solution, $62.8 \mathrm{~J} \mathrm{~s}^{-1} \mathrm{~kg}^{-1}$ for $4 \mathrm{M}$ sodium chloride solution, 57.9 $\mathrm{J} \mathrm{s}^{-1} \mathrm{~kg}^{-1}$ for $2 \mathrm{M}$ sodium chloride solution, $55.4 \mathrm{~J} \mathrm{~s}^{-1} \mathrm{~kg}^{-1}$ for water, $49.1 \mathrm{~J} \mathrm{~s}^{-1} \mathrm{~kg}^{-1}$ for sunflower oil, $46.3 \mathrm{~J} \mathrm{~s}^{-1} \mathrm{~kg}^{-1}$ for Rina vegetable oil, $59.7 \mathrm{~J} \mathrm{~s}^{-1} \mathrm{~kg}^{-1}$ for unused engine oil and $54.1 \mathrm{~J} \mathrm{~s}^{-1} \mathrm{~kg}^{-1}$ for used engine oil. Thermal conductivity of the salt solutions was better than for other heat transfer fluids although they were more corrosive on the system. Thermal efficiencies of the heat transfer fluids were $6 \mathrm{M}$ sodium chloride solution; 0.89, for $4 M$ sodium chloride solution; 0.84 , for $2 \mathrm{M}$ sodium chloride solution; 0.80 , water ; 0.78, sunflower; 0.69, Rina oil ; 0.66, unused engine oil ; 0.75 and used engine oil; 0.71. Storage of solar thermal energy will address the problem of low solar density and its variability. The heat exchanger storage system achieved a thermal capacity of $3.26 \times 10^{3} \mathrm{~kJ}$ at a maximum temperature of $249.4^{\circ} \mathrm{C}$ and at a pressure of 7.2 $\times 10^{5} \mathrm{Nm}^{-2}$. The use of heat exchangers in solar thermal storage will increase the overall efficiency of total system.
\end{abstract}

Keywords: Heat transfer fluids, Heat exchanger team storage, Steam flow rate, Solar radiation

\section{Introduction}

Solar power can be stored and discharged by use of a heat exchanger storage system in which case the storage volume is less expensive than use of the common steam storage systems alone for high power demand. The design equations for the storage systems give a means of finding the interactions of various physical quantities on the operation of heat exchanger [1]. A molten salt storage system was used to provide low cost thermal energy in a study that was found in a solar energy one energy project [2]. Availability of pressurized steam storage facilities hold the key for continued steam supply where a fall in pressure causes production of more steam for utilization. Hence a constant supply pressure is maintained. During the sun shine hours the heat exchanger charged depending on size and discharges on demand. Testing of the heat exchanger was done according to TEMA standards [3]. In this study the shell and coiled tube counter current heat exchanger had two fluids flowing in opposite directions and they were separated by $0.03 \mathrm{~m}$ wall of Copper across which heat was conducted by the liquid at a lower temperature. The first law of thermodynamics is obeyed for all design considerations of fabrication of heat exchangers [4]. In this case the insulation is done to ensure minimum heat losses to the surroundings. A large steam flow rate on the steam supply side resulted into larger amounts of heat transfer and hence higher efficiency of the heat exchanger. The mean temperature difference was a useful parameter in sizing and design of the heat exchanger that served to reduce the cost of steam produced [5]. The cause of heat flow in the heat exchanger was the difference in the temperatures of the fluids in the tube side and the shell side. Turbulent flow produces higher heat transfer compared to laminar flow since it enhances mixing of a fluid [6]. The technology of thermal storage has been developed to an extent where its application has potential of being accepted as another way of storing energy [7]. Hence application of thermal power in the 
tropics by use of available materials can enhance thermal power harnessing and efficiency. The shell and coiled tube heat exchanger was fabricated because it provided a large ratio of heat transfer area to volume and weight. The heat exchanger storage system is a dependable system which when sized appropriately can provide power throughout the day in the tropics. Analytical methods are used to approximate the size of a heat exchanger in order to avoid over sizing and the related unnecessary cost. The overall heat transfer coefficient is calculated assuming that it is constant along all the heat exchanger and can be predicted with convection correlation since there are many factors that affect it. These factors include influence of bubbles and corrosion [8]. A tubular heat exchanger consists of two co axial tubes carrying the hot and the cold fluids. The hot fluid flows in the inner tube and cold fluid flows in the outer annulus [7]. Increase in the storage capacity of a solar thermal power generating will increase the reliability of solar power. This will also increase the efficiency of the solar thermal project.

\subsection{Heat Exchanger Storage Design And Fabrication Design \\ II. Materials And Methods \\ Heat Exchanger Storage System Design}

In the design of coiled tube counter flow heat exchanger the following was done; duty was defined as follows: - heat exchanger operational temperature of $350{ }^{\circ} \mathrm{C}$, at a heat transfer rate of $85.0 \mathrm{Js}^{-1} \mathrm{~kg}^{-1}$, with a steam flow rate of $12.0 \mathrm{~kg} \mathrm{~s}^{-1}$ and a capacity of $0.01 \mathrm{~m}^{3}$. The logarithmic temperature difference was calculated as shown in equation $1[3]$ :

$$
\Delta T_{m}=\frac{\left(T_{i, h}-T_{o, c}\right)-\left(T_{o, h}-T_{i, c}\right)}{\operatorname{In} \frac{\left(T_{i, h}-T_{o, c}\right)}{T_{o, h}-T_{i, c}}}
$$

Where $T_{i, h}$ is the hot fluid inlet temperature, $T_{o, h}$ is the hot fluid outlet temperature, $T_{i, c}$ is the cold fluid inlet temperature and $T_{o, c}$ is the cold fluid outlet temperature.

Heat transfer surface area was calculated using equation 2 as shown [8]:

$Q=U A \Delta T_{m}$

Where $\mathrm{Q}$ is the magnitude of heat transferred, $\mathrm{U}$ is the overall heat transfer coefficient and $\Delta T_{m}$ is the mean logarithmic temperature difference. This was the smallest area that could be used for the heat transfer for the duty defined by optimization. The pressure drop on the shell side was $2081.9 \mathrm{~Pa}$ and on the tube side was 9878.9 $\mathrm{Pa}$. In the shell side water turned into steam on absorbing the heat from the heat transfer fluid that flowed inside the inner copper coiled tube.

Table 1: Summary of mechanical properties of heat exchanger storage system

\begin{tabular}{|l|l|}
\hline Parameter & Steel cylindrical case \\
\hline Axial strain & $2.1 \%$ \\
\hline Axial stress & $100 \mathrm{MPa}$ \\
\hline Modulus of elasticity & $20 \mathrm{M} \mathrm{Pa}$ \\
\hline Load & $1.5 \times 10^{6} \mathrm{~Pa}$ \\
\hline Deflection & $\mathrm{L} / 500$ \\
\hline Thickness & $1.5 \times 10^{-3} \mathrm{~m}$ \\
\hline Moment & $3.6 \times 10^{-3} \mathrm{~N} / \mathrm{M}$ \\
\hline
\end{tabular}

Figure 1 shows the physical quantities involved in heat transfer across a tube in a heat exchanger

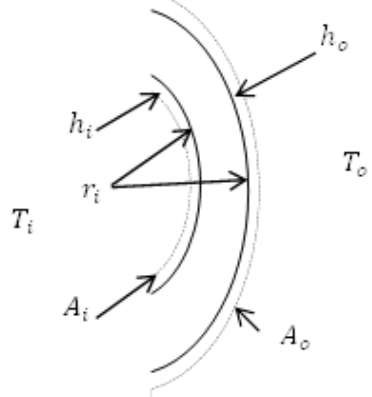

Figure 1: Heat transfer between the absorbing and emitting fluids in exchanger 
From fig. 1, heat is being transferred from the hot fluid at an average temperature of $T_{i}$ through the liquid surrounding the tube to the surrounding liquid (water) at a temperature of $T_{o} . A_{i}$ and $A_{o}$ are the inner and outer surface areas of heat transfer surfaces respectively. The outer heat transfer coefficient $U_{o}$ was obtained from [9] as using equation 1:

$U_{o}=\frac{1}{\frac{A_{0}}{h_{i} A_{i}}+\frac{R_{f i} A_{0}}{A_{i}}+\frac{A_{0} \ln \left(r_{o} \mid r_{i}\right)}{2 \pi L K_{W}}+R_{f o}+\frac{1}{h_{o}}}$

For the inner surface the corresponding heat transfer coefficient was obtained as shown equation 4:

$$
U_{i}=\frac{1}{\frac{1}{h_{i}}+R_{f i}+\frac{A_{i} \ln \left(r_{o} \mid r_{i}\right)}{2 \pi L K_{w}}+\frac{R_{f o} A_{i}}{A_{o}}+\frac{A_{i}}{h_{o} A_{o}}}
$$

Where $A_{i}$ and $A_{o}$ is the internal and external heat transfer area respectively, $h_{i}$ and $h_{o}$ are the internal and external heat transfer coefficients respectively, $r_{i}$ and $r_{o}$ are the internal and external radii of the tube respectively, $K_{w}$ is the thermal conductivity of the tube material, $R_{f o}$ and $R_{f i}$ are the resistances of heat flow externally and internally respectively.

Fig. 2 shows the arrangement of the streams flow of the fluids in the coiled single pass counter flow heat exchanger.

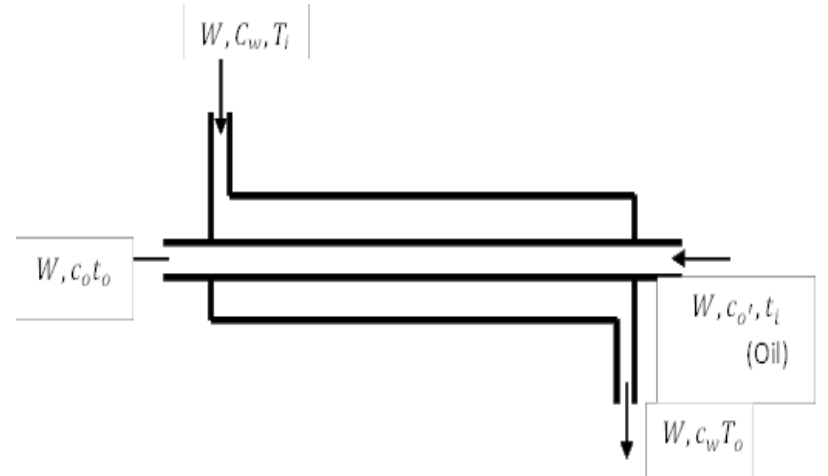

Figure 2: Coiled single pass counter flow heat exchanger

\section{Fabrication Of Heat Exchanger}

To make the shell, its lay out was made on AutoCAD 2010 software and its measurements were used to cut the black iron sheets. It consisted of two hemispheres which were welded together. The dimensions of the heat exchanger steam storage shell were: External diameter of $0.47 \mathrm{~m}$, internal diameter of $0.43 \mathrm{~m}$, length of storage volume of $0.51 \mathrm{~m}$, mass of $49.9 \mathrm{~kg}$, volume capacity of $0.018 \mathrm{~m}^{3}$, inner coiled copper tube's external diameter and internal diameter was $0.36 \mathrm{~m}$ and $0.33 \mathrm{~m}$ respectively, length of coiled copper tube was $1.2 \mathrm{~m}$, shell dome length was $0.019 \mathrm{~m}$, heat transfer fluids inlet tube diameter and the outlet tube diameters were 0.02 $\mathrm{m}$ each respectively and the tube inlet and outlet diameters for water were $0.02 \mathrm{~m}$ and $0.15 \mathrm{~m}$ respectively. The diameter of the water outlet tube was smaller than that of the heat transfer fluids' outlet tube to retain water in the shell for longer period of time. This enhanced the absorption of heat by the water from the heat transfer fluid to make steam. The copper coils spacing was $0.15 \mathrm{~m}$. During fabrication the coiled copper tube of length $1.2 \mathrm{~m}$ and diameter $0.013 \mathrm{~m}$ was positioned in the shell side. Fig. 3 shows the assembly of the coiled tube and shell heat exchanger during fabrication.

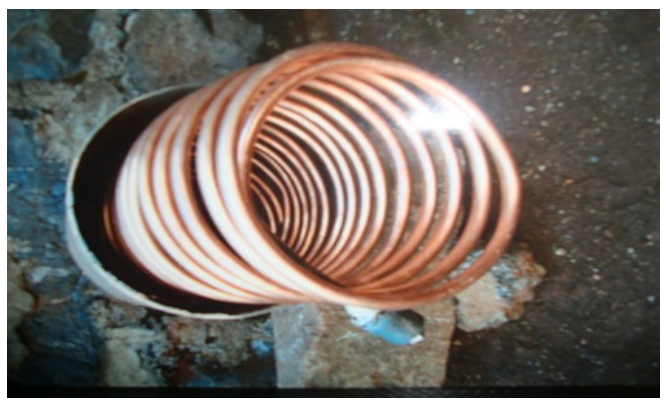

Figure 3: Heat exchanger during assembly 
The tube was supported by $0.05 \times 0.028 \mathrm{~m}$ galvanized cast iron bars that acted as baffles. They supported the coiled tubes in position and reduced the momentum of the coiled tubes under the influence of heat transfer fluid induced eddies. The shell side fluid was water and the tube fluid was heat transfer fluids. Two black iron sheets which were $0.5 \mathrm{~m}$ by $0.6 \mathrm{~m}$ and $0.015 \mathrm{~m}$ were laminated into one sheet using Loctite glue. It was folded into a circular cross-section and was made by machining, rolling and bending into a cylindrical structure and the longitudinal joint was welded. The shell dome was also welded on to the cylindrical structure. Bonnets with threaded connection for the side tube piping were fabricated by machining of seamless galvanized iron pipes. The baffles to support the tube during assembly and operation and prevent vibration of the tubes due to flow induced eddies were welded in position. An expansion joint was put in the shell to control thermal expansion of the shell when the temperatures changed. Insulation of the heat exchanger was done using $0.04 \mathrm{~m}$ of cotton wool. The heat transfer fluid would flow in the tube since it was at a higher pressure. With increase in solar power intensity during the day and the pressurization in the heat exchanger storage system, the shell side achieved a higher pressure. Consequently steam discharge flow rate was higher causing a higher pressure drop on the shell side of the storage system.

The shell side pressure drop was obtained from [7] as shown in equation 5:

$\Delta P a=\frac{2 f_{c} G_{S}^{2}\left(N_{B}+1\right)}{\rho D_{e}\left(\frac{\mu}{\mu_{S}}\right)^{0.14}}$

Where $f_{c}$ is the friction factor for flow on the shell side of shell side as obtained from TEMA guide lines [10], $G_{s}$ is the mass velocity on the shell side, $D_{\theta}$ is the inside diameter of the shell, $N_{B}$ was the number of baffles, $\rho$ was the density of the fluid flowing on the shell side of the heat exchanger, 1 was the tube length and $\mathrm{D}$ was the equivalent diameter.

The tube side pressure drop was obtained as shown in equation 5 [11]:

$\Delta P a=f_{c} \frac{L}{D}\left(\frac{1}{2} \rho V^{2}\right) \times N P$

Where NP was the number of passes

Equation 7 was used to find the number of heat transfer units. This is a measure of the size the heat exchanger.

$\mathrm{NTU}=\frac{U A}{\left(m \cdot c_{p}\right)_{\min }}$

$c_{\min }$ is the smaller of the two heat capacity rates for the heat transfer fluids, $\mathrm{U}$ is the overall heat transfer coefficient, $\mathrm{A}$ is the heat transfer surface area and $\mathrm{m}$ is the mass flow rate.

The overall heat transfer conductance was obtained as shown in equation 2[12]. Thermal conductivity of copper tube used was $26 \mathrm{~W} / \mathrm{m} \mathrm{K}$ [13]. Effectiveness of the heat exchanger was the measure of the amount of heat that was transferred between the hot fluid and the cold fluid which were normalized with the maximum possible enthalpy change, considering no losses. The effectiveness, E, of the heat exchanger was hence obtained using equation 8 :

$E=\frac{\text { Actual heat transfer }}{\text { Maximum possibleheat transf } \theta r}$

The steam formed would exit from the shell side outlet connection to the turbine. Heat transfer coefficients for the heat transfer fluids were calculated by use of values obtained from fluids coefficients tables [14]. Area of baffles was $0.003 \mathrm{~m}^{2}$, Tube spacing was $0.05 \mathrm{~m}$ and the heat transfer liquid average velocity was $8.0 \mathrm{~m} / \mathrm{s}$. Temperature efficiencies of the heat exchanger streams are an important measure of performance of a heat exchanger. The temperature efficiency of the hot stream was calculated from equation 9 [8]:

$\eta_{h t}=\frac{T_{i, h}-T_{o, h}}{T_{i, h}-T_{i, c}} \times 100$

The temperature efficiency of the cold fluid was calculated using equation 10 [8]:

$\eta_{c d}=\frac{T_{o, c}-T_{i, c}}{T_{i, h}-T_{i, c}} \times 100$

Where $T_{o, c}$ was the outlet temperature of the cold sream, $T_{i, c}$ was the inlet temperature of cold stream, $T_{o . h}$ was the outlet temperature of the hot stream and $T_{i, h}$ was the inlet temperature of the hot stream.

\subsection{Heat Exchanger Steam Storage System Charging And Discharging}

The heat exchanger steam storage system was charged during the day and was discharged on demand. It required three and half hours to be charged to a capacity of $3.26 \times 10^{3} \mathrm{~kJ}$ at a maximum temperature of $249.4{ }^{\circ} \mathrm{C}$ and a pressure of $7.2 \times 10^{5} \mathrm{Nm}^{-2}$ at solar irradiance of $1097 \mathrm{Wm}^{-2}$. The safety valve was installed on the heat exchanger storage steam inlet tube to ensure that it does not exceed the set pressure. During charging 
$0.004 \mathrm{~m}^{3}$ of cold water was put in the shell and the steam exit valve to the turbine was closed. Hot heat transfer fluid from the solar collector flowed in the tube side of the heat exchanger and heated the water to steam. Steam pressure was allowed to build up to the set pressure after which the steam control discharge valve would be opened. The steam was proceeding to the main storage system where it was pressurized further. When there was over cast weather and the heat exchanger storage was fully charged, discharge would produce lower pressure in the shell side. The pressure drop caused flashing of steam from the shell side and hence more steam would be discharged for the turbine thermal energy conversion. The sizing of the heat exchanger steam storage system was undertaken by consideration of the following design parameters: - Maximum continuous rating of 60 $\mathrm{kg} h^{-1}$, the working pressure between $1.0 \times 10^{5} \mathrm{Nm}^{-2}$ and $1.0 \times 10^{6} \mathrm{Nm}^{-2}$, maximum instantaneous demand of $40 \mathrm{~kg} h^{-1}$ and mean value of overload used to size the heat exchanger storage system was 40 $\mathrm{kg} h^{-1}$. The mean off peak load at night time was approximated from the anticipated users of the power at 500 $\mathrm{W}$ load and used in off peak sizing calculation. The steam storage capacity was calculated using equation 11: $C_{s t}=\frac{Q_{d \times m_{W}}}{Q_{e}}$

Where $C_{s t}$ was the steam storage capacity, $Q_{d}$ was the difference in enthalpy of water, $m_{w}$ was the mas of water and $Q_{\theta}$ was the enthalpy of evaporation at lower pressure.

\subsection{Heat Exchanger Testing}

The testing loop shown in figure 4 was used in testing of the heat exchanger. The system was allowed to reach steady state. The readings of pressure and temperature were taken three times at half hour intervals to ensure that steady state had been achieved whereby the readings obtained for the parameters varied by less than $1 \%$. TEMA guide lines [3] were considered during the testing. In the testing of the heat exchanger storage system, the boiler was set at a pressure of $5.0 \times 10^{6} \mathrm{Nm}^{-2}$ and the inlet temperatures of operation was fixed using a thermostat to $300{ }^{\circ} \mathrm{C}$ The flow loop was run for thirty minutes to obtain steady state operating conditions using equation 12 :

$\dot{Q}=\dot{m} c_{p}\left(T-T_{a}\right)$

Where $\dot{Q}$ was the rate of heat transfer, $\dot{m}$ was the mass flow rate, $\mathrm{T}$ was the temperature of operation, $T_{a}$ was the ambient temperature and $c_{p}$ specific heat capacity of storage fluid. The thermostat was set at the inlet test temperatures of $150{ }^{\circ} \mathrm{C}, 200{ }^{\circ} \mathrm{C}, 250{ }^{\circ} \mathrm{C}, 250{ }^{\circ} \mathrm{C}$ and $300{ }^{\circ} \mathrm{C}$ to ensure a constant temperature for a particular flow rate.

At steady state it was assumed that the rate of heat flow was constant for the heat exchanger storage system. This was assumed so since insulation kept heat loses to a minimum. The steady position of the system ensured that variations and errors of measurements were minimum. Non return valve closed down when the steam flow stopped to flow in the heat exchanger storage system hence preventing back flow of steam to the parabolic solar collector during solar thermal collection. The inlet and out let temperatures of heat transfer liquids were measured. The quantities that were used to find the percentage losses and gains were amount of heat emitted from hot liquid and amount of heat absorbed by the cold liquid. The following were also measured: mass flow rates of hot and cold heat transfer fluids respectively, inlet and outlet enthalpies of the cold and hot fluids were calculated respectively, inlet and outlet temperatures of hot and cold fluids respectively, specific heats of cold and hot fluids and the steam flow rates and enthalpy of the steam produced. Fig. 4 shows the heat exchanger steam storage testing loop. The characteristic properties of the storage system were obtained from the measurements that were taken from the set up.

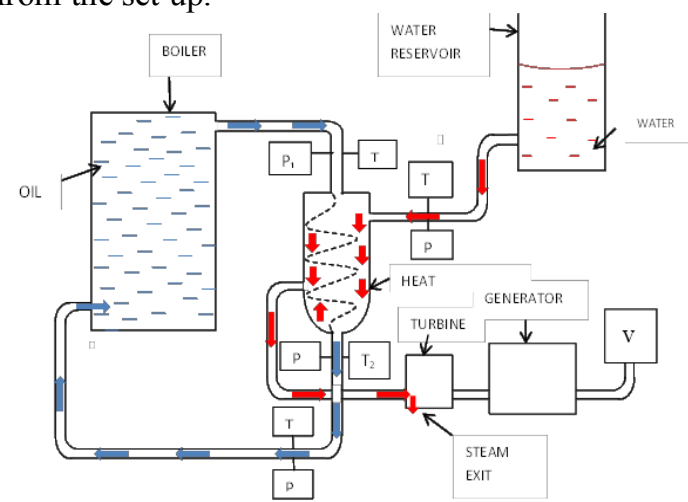

Figure 4: Heat exchanger steam storage testing loop 
The temperature efficiencies of the streams was calculated by measuring the temperature changes in each of the fluid stream and was compared with the maximum temperature difference between the two fluid streams. The heat lost and the heat gained was evaluated using the temperature measurements obtained.

Fig. 5 shows the use of heat exchanger as a steam storage system.



Figure 5: Use of heat exchanger as a storage system

The heat exchanger was feeding the main steam storage system with steam that was supplied to the turbine for power generation. The heat transfer fluids flowed in the tube side of the exchanger and they heated the water on the shell side during charging and during the discharge the steam exit control valve was opened. The steam exit valve allowed the steam to move into the turbine.

\section{Results And Discussion}

The heat exchanger storage system was tested and the results are presented. Brief characteristics of the heat exchanger storage system are shown. The coiled inner tube was made of copper since it is a good conductor of heat. The heat exchanger surface area, A, was obtained as $0.05 \mathrm{~m}^{2}$. The heat exchanger steam storage discharge capacity was $30 \mathrm{~kg} \mathrm{~h}-1$ of flashing steam. The overall heat coefficient was calculated and found to be $420 \mathrm{~W} / \mathrm{m}^{20} \mathrm{C}$. The mean logarithmic temperature difference, $\Delta T_{m}$, was calculated and obtained as 89.6. An increase in the steam flow rate on the shell side of the heat exchanger caused more pressure drop. The heat exchanger had a thermal capacity of $3.26 \times 10^{3} \mathrm{~kJ}$ at a maximum temperature of $249.4{ }^{\circ} \mathrm{C}$ and at a pressure of $7.2 \times 10^{5} \mathrm{Nm}^{-2}$. The temperature efficiencies of the hot stream and that of the cold stream were found to be $89.7 \%$ and $92.1 \%$ respectively. The operating points of the heat exchanger when used as a heat storage system are as shown in tables $1-8$.

Heat Exchanger Operating Points

The heat exchanger operating points for heat exchanger steam storage were as follows:

\section{Vegetable Oil Vs Water}

Table 2: Operating points for vegetable oil and water fluids

\begin{tabular}{|l|l|l|}
\hline & Hot fluid (Vegetable oil) & Cold fluid(Water) \\
\hline Mass flow rate $(\mathrm{kg} / \mathrm{s})$ & 4.8 & 3.7 \\
\hline Volume flow rate $\left(\mathrm{m}^{3} / \mathrm{s}\right)$ & 4.9 & 3.3 \\
\hline Fluid Pressure $\left(\mathrm{Nm}^{-2}\right)$ & 5.0 & 5.0 \\
\hline Density $\left(\mathrm{kg} / \mathrm{m}^{3}\right)$ & 915 & 1000 \\
\hline Specific heat, $C_{p}, \mathrm{Jg}^{-1{ }^{\circ} \mathrm{C}^{-1}}$ & 912.8 & 4170 \\
\hline$T_{2, \text { out }}{ }^{\circ} \mathrm{C}$ & 34.3 & 143.7 \\
\hline$T_{1 \text { in }}{ }^{\circ} \mathrm{C}$ & 161.2 & 24.1 \\
\hline
\end{tabular}

\section{Sunflower Oil Vs Water}


Table 3: Operating points for sunflower and water fluids

\begin{tabular}{|l|l|l|}
\hline & Hot fluid (sunflower) & Cold fluid (Water) \\
\hline Mass flow rate $(\mathrm{kg} / \mathrm{s})$ & 5.6 & 4.9 \\
\hline Volume flow rate $\left(\mathrm{m}^{3} / \mathrm{s}\right)$ & 4.89 & 4.4 \\
\hline Fluid Pressure $\left(\mathrm{Nm}^{-2}\right)$ & 5.0 & 5.0 \\
\hline Density $\left(\mathrm{kg} / \mathrm{m}^{3}\right)$ & 1004 & 0.905 \\
\hline Specific heat, $C_{p}, \mathrm{Jkg}^{-1}{ }^{\circ} \mathrm{C}^{-1}$ & 2500 & 4170 \\
\hline$T_{2, \text { out }}{ }^{\circ} \mathrm{C}$ & 32.9 & 165.6 \\
\hline$T_{1, \text { in }}{ }^{\circ} \mathrm{C}$ & 16.7 & 23.4 \\
\hline
\end{tabular}

\section{Water Vs Water}

Table 4: Operating points for water and water fluids

\begin{tabular}{|l|l|l|}
\hline & Hot fluid (water) & Cold fluid (water) \\
\hline Mass flow rate $(\mathrm{kg} / \mathrm{s})$ & 7.5 & 6.8 \\
\hline Volume flow rate $\left(\mathrm{m}^{3} / \mathrm{s}\right)$ & 6.9 & 6.5 \\
\hline Fluid Pressure $\left(\mathrm{Nm}^{-2}\right)$ & 5.0 & 5.0 \\
\hline Density $\left(\mathrm{kg} / \mathrm{m}^{3}\right)$ & 1000.0 & 1000.0 \\
\hline Specific heat, $C_{p}, \mathrm{Jkg}^{-1}{ }^{\circ} \mathrm{C}^{-1}$ & 4180.0 & 4180.0 \\
\hline$T_{2, \text { out }}{ }^{\circ} \mathrm{C}$ & 30.4 & 279.6 \\
\hline$T_{1 \text { in }}{ }^{\circ} \mathrm{C}$ & 278.8 & 22.2 \\
\hline
\end{tabular}

\section{Unused Engine Oil Vs Water}

Table 5: Operating points for used oil and water fluids

\begin{tabular}{|l|l|l|}
\hline & Hot fluid (Used engine oil) & $\begin{array}{l}\text { Cold fluid } \\
\text { (Water) }\end{array}$ \\
\hline Mass flow rate $(\mathrm{kg} / \mathrm{s})$ & 7.8 & 7.2 \\
\hline Volume flow rate $\left(\mathrm{m}^{3} / \mathrm{s}\right)$ & 6.4 & 6.8 \\
\hline Fluid Pressure $\left(\mathrm{Nm}^{-2}\right)$ & 5.0 & 5.0 \\
\hline Density $\left(\mathrm{kg} / \mathrm{m}^{3}\right)$ & 800 & 1000.0 \\
\hline Specific heat, $C_{p}, \mathrm{Jkg}^{-1}{ }^{\circ} \mathrm{C}^{-1}$ & 2500 & 4180.0 \\
\hline$T_{2, \text { out }}{ }^{\circ} \mathrm{C}$ & 32.7 & 241.3 \\
\hline$T_{1, \text { in }}{ }^{\circ} \mathrm{C}$ & 237.8 & 21.9 \\
\hline
\end{tabular}

\section{Used Engine Oil Vs Water}

Table 6: Operating points for unused engine oil and water

\begin{tabular}{|l|l|l|}
\hline & Hot fluid (Unused engine oil) & Cold fluid (Water) \\
\hline Mass flow rate $(\mathrm{kg} / \mathrm{s})$ & 7.6 & 6.6 \\
\hline Volume flow rate $\left(\mathrm{m}^{3} / \mathrm{s}\right)$ & 6.9 & 6.1 \\
\hline Fluid Pressure $\left(\mathrm{Nm}^{-2}\right)$ & 5.0 & 5.0 \\
\hline Density $\left(\mathrm{kg} / \mathrm{m}^{3}\right)$ & 1025.0 & 1000 \\
\hline Specific heat, $C_{p}, \mathrm{Jkg}^{-1}{ }^{\circ} \mathrm{C}^{-1}$ & 5200.0 & 4180 \\
\hline$T_{2, \text { out }}{ }^{\circ} \mathrm{C}$ & 31.5 & 264.7 \\
\hline$T_{1 \text { in }}{ }^{\circ} \mathrm{C}$ & 271.3 & 22.4 \\
\hline
\end{tabular}

\section{2m Salt Solution Vs Water}


Table 7: Operating points for $2 \mathrm{M}$ sodium chloride solution

\begin{tabular}{|l|l|l|}
\hline & Hot fluid (2 M salt solution & Cold fluid (Water) \\
\hline Mass flow rate $(\mathrm{kg} / \mathrm{s})$ & 7.8 & 6.7 \\
\hline Volume flow rate $\left(\mathrm{m}^{3} / \mathrm{s}\right)$ & 6.8 & 6.2 \\
\hline Fluid Pressure $\left(\mathrm{Nm}^{-2}\right)$ & 5.0 & 5.0 \\
\hline Density $\left(\mathrm{kg} / \mathrm{m}^{3}\right)$ & 1050.0 & 1030 \\
\hline Specific heat, $C_{p}, \mathrm{Jkg}^{-1{ }^{\circ} \mathrm{C}^{-1}}$ & 3980.0 & 1000 \\
\hline$T_{2, \text { out }}{ }^{\circ} \mathrm{C}$ & 31.4 & 264.9 \\
\hline$T_{1, \text { in }}{ }^{\circ} \mathrm{C}$ & 271 & 22.1 \\
\hline
\end{tabular}

\section{4m Salt Solution Vs Water}

Table 8: Operating points for $4 \mathrm{M}$ sodium chloride solution

\begin{tabular}{|l|l|l|}
\hline & Hot fluid (4 M salt solution & Cold fluid (Water) \\
\hline Mass flow rate $(\mathrm{kg} / \mathrm{s})$ & 7.9 & 6.8 \\
\hline Volume flow rate $\left(\mathrm{m}^{3} / \mathrm{s}\right)$ & 6.7 & 6.2 \\
\hline Fluid Pressure $\left(\mathrm{Nm}^{-2}\right)$ & 5.0 & 5.0 \\
\hline Density $(\mathrm{kg} / \mathrm{m} 3)$ & 1030.0 & 1000 \\
\hline Specific heat, $C_{p,} \mathrm{Jkg}^{-1}{ }^{\circ} \mathrm{C}^{-1}$ & 3910 & 3910 \\
\hline$T_{2, \text { out }}{ }^{\circ} \mathrm{C}$ & 33.7 & 276.1 \\
\hline$T_{1, \text { in }}{ }^{\circ} \mathrm{C}$ & 278.8 & 21.9 \\
\hline
\end{tabular}

\section{6m Salt Solution}

Table 9: Operating points for $6 \mathrm{M}$ sodium chloride solution

\begin{tabular}{|l|l|l|}
\hline & Hot fluid (6 M salt solution & Cold fluid (Water) \\
\hline Mass flow rate $(\mathrm{kg} / \mathrm{s})$ & 8.2 & 7.4 \\
\hline Volume flow rate $\left(\mathrm{m}^{3} / \mathrm{s}\right)$ & 7.9 & 6.8 \\
\hline Fluid Pressure $\left(\mathrm{Nm}^{-2}\right)$ & 5.0 & 5.0 \\
\hline Density $\left(\mathrm{kg} / \mathrm{m}^{3}\right)$ & 1030.0 & 1000 \\
\hline Specific heat, $\mathrm{C}_{p}, \mathrm{Jkg}^{-1}{ }^{\circ} \mathrm{C}^{-1}$ & 3850.0 & 3850 \\
\hline$T_{2, \text { out }}{ }^{\circ} \mathrm{C}$ & 35.9 & 283.4 \\
\hline$T_{1, \text { in }}{ }^{\circ} \mathrm{C}$ & 283.8 & 22.6 \\
\hline
\end{tabular}

The overall heat transfer conductance, $\mathrm{UA}, \mathrm{W} /{ }^{0} \mathrm{C}$ was calculated using equation 7 to be $22.4 \mathrm{~W} /{ }^{\circ} \mathrm{C}$. The rate of heat transfer was an average of $68.4 \mathrm{~J} / \mathrm{s} / \mathrm{kg}$ for $6 \mathrm{M}$ sodium chloride solution, $62.8 \mathrm{~J} / \mathrm{s} / \mathrm{kg}$ for $4 \mathrm{M}$ sodium chloride solution, $57.9 \mathrm{~J} / \mathrm{s} / \mathrm{kg}$ for $2 \mathrm{M}$ sodium chloride solution, $55.4 \mathrm{~J} / \mathrm{s} / \mathrm{kg}$ for water, $49.1 \mathrm{~J} / \mathrm{s} / \mathrm{kg}$ for sun flower oil, $46.3 \mathrm{~J} / \mathrm{s} / \mathrm{kg}$ for Rina oil, $59.7 \mathrm{~J} / \mathrm{s} / \mathrm{kg}$ for unused engine oil and $54.1 \mathrm{~J} / \mathrm{s} / \mathrm{kg}$ for used engine oil. The number of heat transfer units, NTU was obtained from [7] as 5.64 by use of equation 7.

Table 10: Rates of heat transfer and temperature efficiency of heat transfer fluids

\begin{tabular}{|c|c|c|}
\hline Heat transfer oil & $\begin{array}{c}\text { Rate of heat } \\
\operatorname{transfer}(\mathrm{J} / \mathrm{s} / \mathrm{kg})\end{array}$ & $\begin{array}{c}\text { Temperature } \\
\text { efficiency }\end{array}$ \\
\hline $\begin{array}{c}6 \mathrm{M} \text { sodium chloride } \\
\text { solution }\end{array}$ & 68.4 & 0.88 \\
\hline $\begin{array}{c}4 \mathrm{M} \text { sodium chloride } \\
\text { solution }\end{array}$ & 62.8 & 0.84 \\
\hline $\begin{array}{c}2 \mathrm{M} \text { sodium chloride } \\
\text { solution }\end{array}$ & 57.9 & 0.81 \\
\hline Water & 55.4 & 0.78 \\
\hline Sun flower oil & 49.1 & 0.69 \\
\hline Rina vegetable oil & 46.3 & 0.66 \\
\hline Unused engine oil & 59.7 & 0.76 \\
\hline Used engine oil & 54.1 & 0.72 \\
\hline
\end{tabular}


Table 10 shows rates of flow of the heat transfer fluids and the temperature efficiencies obtained in the heat transmission to the cold water. The temperature efficiencies of the salt solutions were higher than those of the other heat transfer fluids since they had higher thermal conductivity. Table 11 shows the maximum temperatures obtained for the heat exchanger storage system using the heat transfer fluids. This was due to the pressurization that took place during charging of the heat exchanger during sunshine hours.

Table 11: Maximum steam temperatures for heat exchanger storage system

\begin{tabular}{|l|l|}
\hline Heat transfer oil & Heat Exchanger max. tempt \\
\hline 6 M sodium chloride solution & 312.3 \\
\hline 4 M sodium chloride solution & 301.6 \\
\hline 2 M sodium chloride solution & 293.6 \\
\hline Water & 263.9 \\
\hline Sunflower oil & 211.2 \\
\hline Rina vegetable oil & 167.4 \\
\hline Unused vegetable oil & 268.5 \\
\hline Used engine oil & 210.7 \\
\hline
\end{tabular}

Fig. 6 - 11 show the steam mass flow rates $(\mathrm{kg} / \mathrm{s})$ for the heat transfer fluids against steam temperatures obtained for the heat exchanger storage system. The temperature of steam discharged increased with the increase in the steam flow rate. Pressurization of the steam increased the enthalpy of water hence temperature increase for the steam. The steam obtained with inorganic solutions had higher temperatures compared to the one obtained from organic oils. This was because the inorganic fluids had higher thermal conductivity. The steam obtained from unused engine oil had higher temperature compared to the one obtained from used engine oil. This was because the used engine oil undergoes a faster thermal degradation compared to the unused engine oil since the used engine oil is degraded oil containing carbon and other byproducts. The unused engine oil had a lower thermal conductivity compared to the unused engine oil.

Fig. 7 shows that the disparity between the $2 \mathrm{M}$ sodium chloride solution and sun flower heat transfer fluids. This was because the salt solution has higher thermal conductivity compared to sunflower oil and therefore more steam was generated when $2 \mathrm{M}$ sodium chloride solution was used than when sunflower oil was used. Figure. 9 shows the variations of steam flow rates between Unused engine oil and water. Water has a higher specific heat capacity compared to the engine oil and therefore initially steam flow rate of Unused engine oil was higher than that of water. However as the temperatures of operation increased the oil started to degrade and the water achieved higher steam flow rates compared to unused engine oil.

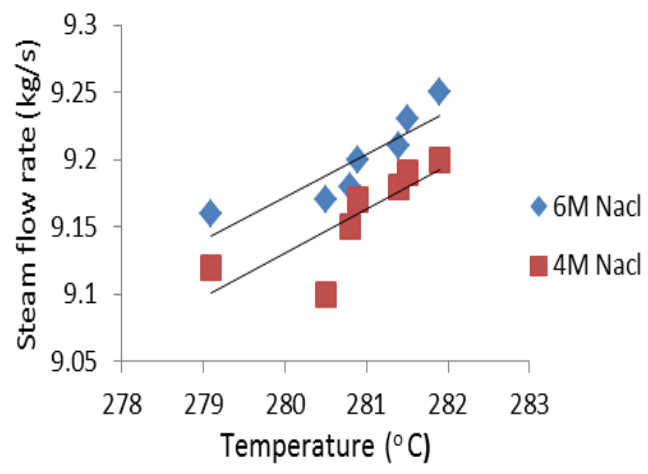

Figure 6: Steam flow rate against temperature for $6 \mathrm{M}$ and $4 \mathrm{M} \mathrm{NaCl}$ solution

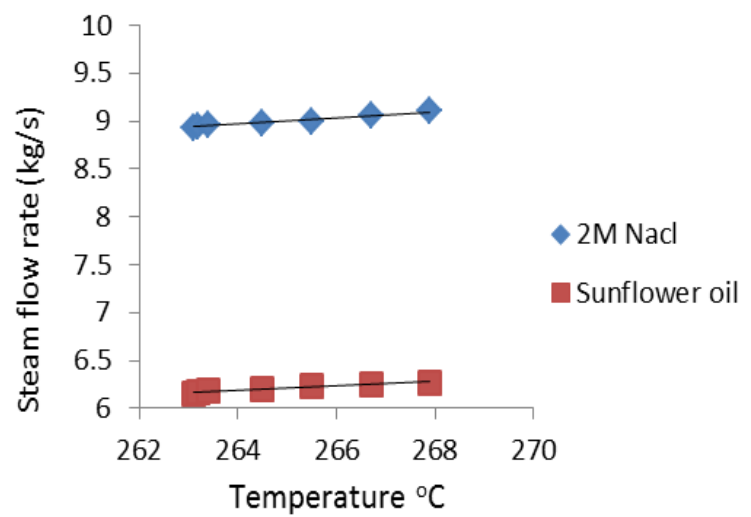


Figure 7: Steam flow rate against temperature for $2 \mathrm{M} \mathrm{NaCl}$ solution and sunflower oil

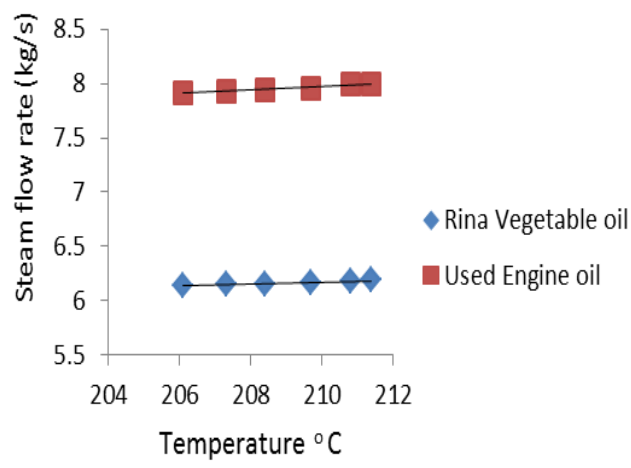

Figure 8: Steam flow rate against temperature for Rina vegetable oil and Used Engine oil

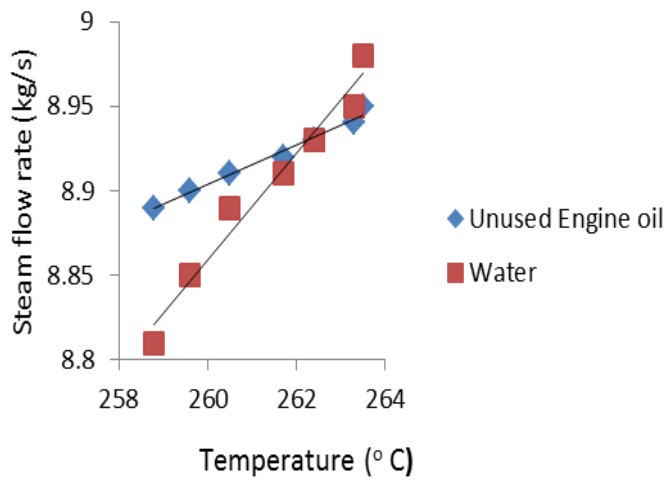

Figure 9: Steam flow rate against temperature for Unused Engine oil and Water

When temperature of the heat transfer oil increased beyond $250{ }^{\circ} \mathrm{C}$ the resistance to absorption of heat was calculated to rise at the rate $1.8 \mathrm{~W} / \mathrm{m}^{2}{ }^{\circ} \mathrm{C}$ while for temperatures below $200{ }^{\circ} \mathrm{C}$ the resistance was $1.4 \mathrm{~W} / \mathrm{m}^{2}$ ${ }^{\circ} \mathrm{C}$.

\section{Conclusions}

The heat exchanger storage system presents a means of increasing steam output for more solar power production during the sun shine hours in the tropics. This storage system operated at a thermal capacity of 3.26 $\times 10^{3} \mathrm{k} \mathrm{J}$, maximum temperature of $249.5{ }^{\circ} \mathrm{C}$ and a pressure of $7.2 \times 10^{5} \mathrm{Nm}^{-2}$. This compares well with other storage systems used. The current maximum thermal storage temperature is $567{ }^{\circ} \mathrm{C}$ in direct salt storage in a central receiver tower [15]. Increased storage is necessary to cater for unpredictable transients in solar intensity due to overcast skies and at night time. Solar one power plant was using heliostats with a receiver diameter of $0.07 \mathrm{~m}$, storage of thermocline rock oil, granite sand and Caloria HT 43 oil. It operated at a thermal storage capacity of $522 \mathrm{GJ}$, at a maximum temperature of $304{ }^{\circ} \mathrm{C}$ and a operation time of four hours dispensing $7 \mathrm{MW}$ of power [15]. Use of local materials and technology in design and fabrication reduces the cost of steam produced. The most prominent salt used for solar thermal storage is the solar salt that operates in the temperature range of $260{ }^{\circ} \mathrm{C}$ and $567{ }^{\circ} \mathrm{C}$ and that currently, the maximum operational steam conditions are 500 ${ }^{\circ} \mathrm{C}$ at a temperature of $1.2 \times 10^{7} \mathrm{Nm}^{-2}$ [16]. The heat exchanger storage system compared well with other storage system around the world such as Coolidge storage irrigation facility with a thermal capacity of $19.8 \mathrm{GJ}$ and operating at a maximum temperature of $288^{\circ} \mathrm{C}$, Shenandoa Solar total energy project has thermal capacity of $1.33 \mathrm{GJ}$ and operates at a maximum temperature of $363^{\circ} \mathrm{C}$, Invapah solar generating facility uses molten salt and has a storage efficiency of $98 \%$ and Jonhson and Johnson solar total energy project has a thermal capacity of $29.3 \mathrm{GJ}$ and an efficiency of $96.7 \%$ [17]. A means of reducing tube vibrations that are caused by eddying motion of the fluid in the wake of the tube needs to be investigated. This caused considerable wear and tear on the coiled tube. The heat exchanger steam storage can ensure solar power reliability and more power per unit time for areas that are off the grid due to terrain. 


\section{References}

[1]. Kaka C.S, Boilers, Evaporators and Condensers. New York: Wiley and Sons, 1990.

[2]. Rai G.D., Solar Energy Utilization. NewDehli: Hama Publishers, 1987, New Dehli.

[3]. Bowels J. E, Foundation analysis and Design. Newyork: Mc Grawhill, 1996.

[4]. Kroger D. G, “Air cooled heat exchangers and cooling towers, thermal flow performance evaluation and design, "Penwell. Science Journal, Vol 1, pp 342, may 1989.

[5]. Schimidt F.W and Joan W.A., Thermal Energy Storage and Regeneration. Hemisphere Publishing Corporation. London, 1981.

[6]. Schlunder E.U., Heat Exchanger Hand Book. Hemisphere, 1983.

[7]. Singh K. P., Theory and Practice of Heat Exchanger Design, Hemisphere, 1989.

[8]. Shah R. K. and Sekuli D.P., Fundamentals of Heat Exchanger Design, Wiley, 2003

[9]. Incopera F.P, Dewitt D.P, Bergyman T.L and Laving A.S, Fundamentals of Heat and Mass Transfer. London: Wiley, 2007.

[10]. Tubular Heat Exchangers' Manufacturer's Association (TEMA), 'Pressure Vessel Code - alternate rules', Section V, Division 3, New York, 1993.

[11]. Stevenson and William, Elements of Power Systems Analysis. New York: Mc Graw Hill, 2001

[12]. Saunders E.A.D, Heat Exchangers. London: Longman, 1988. London.

[13]. Hewitt G. F, Heat Exchanger Design Hand Book. United Kingdom: Begell House, 2002.

[14]. Nicholas P Chopey, Hand Book for Chemical Engineering Calculations. London: Mc GrawHill, 2007.

[15]. Medrano M., Gil A., Martorrel I., Potau X and Cabeza L.F., (2010), Renewable and Sustenable Energy Reviews. New York.

[16]. Stine W.B. and Harrigan R. W., (1985), Solar Energy Systems and Design, John Wiley. New York.

[17]. Pilkington Solar International GmbH, (1999), Survey of Thermal Storage for Parabolic Trough Power Plants', Report prepared for and Published by NREL, NREL /SR- 550 - 27925, Golden, CO.

[18]. Energy Technology Systems Analysis Program, (2013), Thermal Energy Storage. International Renewable Energy Agency (IRENA). Technology brief EIT. 